\title{
Coagulation Factor Gene
}

National Cancer Institute

\section{Source}

National Cancer Institute. Coagulation Factor Gene. NCI Thesaurus. Code C28480.

Coagulation Factor Genes encode endogenous Coagulation Factors, involved in blood coagulation. $(\mathrm{NCl})$ 